\title{
Hubungan pemakaian alat kontrasepsi IUD dengan tingkat kenyamanan dalam melakukan hubungan seksual
}

\author{
Rilyani" $^{1 *}$, Soni Obit Saputra² \\ Program Studi IImu Keperawatan Universitas Malahayati. *Email : simahayarily@gmail.com
}

\section{Abstract \\ Women's sexual satisfaction after using intrauterine device (IUD) for contraception}

Background: The results of the 2017 population survey population growth rate in Indonesia (1.49\%) and the birth rate is 2.6 / fertile women. The results of the prevalence of family planning in Indonesia in $2013(65.4 \%)$ with injectable contraceptive methods (36\%), pills (15.1\%), Implants (5.2\%), IUDs (4.7\%), and tubectomy (2), $2 \%)$. In Lampung Province recorded in 2016 the type of IUD reached 8,950.89 CCA (couples of childbearing age) experienced an increase in 2015 from 10,235,542, reaching 911 acceptors.

Purpose: To knowing of Women's sexual satisfaction after using intrauterine device (IUD) for contraception

Method: An analytical survey with a cross sectional approach, the population was all women who use intrauterine device (IUD) or others method for contraception with a sample of 91 respondents by random sampling where 71 respondents using an IUD and 20 respondent others method.

Results: the average of women's sexual satisfaction after using intrauterine device (iud) for contraception of 91 respondents means 0.78 standard deviations 0.416 standard errors 0.044 standard errors 0.044 and minimum values max $0-1$. The sexual satisfaction means the value is 0.78 standard deviation 0.477 standard error 0.050 min-max $0-1$. Chi square statistical test results obtained $p$ value $(0.006<0.05)$

Conclusion: There was an effect of women's sexual satisfaction after using intrauterine device (iud) for contraception. Health workers especially nurses can further enhance their skills through the latest literature, training and counseling at every examination of mothers with contraceptive users IUD thus has knowledge of the effects of using an IUD contraceptive.

\section{Keywords: Women; Sexual satisfaction; Intrauterine Device (IUD); Contraception}

Pendahuluan: Hasil survey penduduk tahun 2017 laju pertumbuhan penduduk di Indonesia 1,49\% dan angka kelahiran 2,6 / wanita subur. Hasil prevalensi KB di Indonesia tahun 2013 65,4\% dengan metode KB suntik, (36\%), pil KB (15,1\%), Implant (5,2\%), IUD (4,7\%), dan MOW (2,2\%). BKKBN Provinsi Lampung tahun 2016 KB jenis IUD mencapai 8.950.89 PUS (Pasangan Usia Subur). Mengalami peningkatan di tahun 2015 sebanyak 10.235.542.

Tujuan: Mengetahui Hubungan Pemakaian Alat Kontrasepsi IUD Dengan Tingkat Kenyamanan Dalam Melakukan Hubungan Seksual

Metode : Penelitian ini menggunakan survei analitik dengan pendekatan cross sectional ada hubungan antara factor resiko dengan efek atau observasi antar variable dilakukan secara bersamaan, dengan sampling 91 responden dengan teknik random sampling.

Hasil : Hasil uji statistik chi square didapatkan nilai p value $(0,006<0,05)$ artinya Ho diterima dapat disimpulkan ada hubungan yang bermakna pemakaian alat kontrasepsi IUD dengan tingkat kenyamanan melakukan hubungan seksual. OR didapat dapat 4.105 yang artinya responden yang memakai alat kontrasepsi IUD memiliki resiko lebih besar 5.105 kali ada masalah tingkat kenyamanan melakukan hubungan seksual di bandingkan dengan responden yang tidak menggunakan alat kontrasepsi IUD.

Simpulan : terdapat hubungan menggunkan alat kontrasepsi IUD dengan tingkat kenyamanan melakukan hubungan seksual. Petugas kesehatan khusunya perawat agar dapat lebih meningkatkan keterampilan melalui literatur terbaru, pelatihan serta konseling pada setiap pemeriksaan ibu dengan pengguna alat kontrasepsi IUD sehingga memiliki pengetahuan tentang efek dari penggunaan alat kontrasepsi IUD.

Kata kunci : Pengguna kontrasepsi IUD; Kenyamanan; Hubungan seksual 
Hubungan pemakaian alat kontrasepsi IUD dengan tingkat kenyamanan dalam melakukan hubungan seksual

\section{PENDAHULUAN}

Keluarga Berencana) adalah tindakan yang membantu individu atau pasangan suami istri untuk mendapatkan objektif tertentu, menghindari kelahiran yang tidak diinginkan, mendapatkan kelahiran yang memang diinginkan, mengatur interval di antara kehamilan, mengontrol waktu saat kelahiran dalam hubungan dengan umur suami istri dan menentukan jumlah anak dalam keluarga (World Health Organisation, 2011). Program KB tidak hanya bertujuan untuk mengendalikan laju pertumbuhan penduduk, melainkan juga untuk memenuhi permintaan masyarakat akan pelayanan KB dan Kesehatan Reproduksi (KR) yang berkualitas, menurut angka kematian ibu (AKI) dan angka kematian bayi (AKB) serta serta penanggulangan masalah kesehatan reproduksi untuk membentuk keluarga kecil berkualitas (Sumiasih, 2018).

Berdasarkan hasil survei penduduk tahun 2010 laju pertumbuhan penduduk di Indonesia sebesar 1,49\% dan angka kelahiran total atau Total Fertility Rate (TFR) sebesar 2,6 per wanita subur. Angka tersebut masih jauh dari target Rencana Pembangunan Jangka Menengah Nasional (RPJMN) tahun 2009-2014 yaitu tercapainya laju pertumbuhan penduduk (LPP) sebesar 1,1\% dan tingkat fertilitas 2,1\% per kelahiran (Badan Kependudukan dan Keluarga Berencana Nasional, 2013). Dalam mengatasi pertumbuhan penduduk pemerintah menerapkan kebijakan penggunaan kontrasepsi yang rasional, efektif dan efisien diantaranya yaitu penggunaan MKJP.

Hasil prevalensi KB di Indonesia berdasarkan Survei Pemantauan Pasangan Usia Subur tahun 2013 mencapai angka 65,4\% dengan metode KB yang didominasi oleh peserta KB suntikan (36\%), pil KB $(15,1 \%)$, Implant $(5,2 \%)$, IUD $(4,7 \%)$, dan MOW $(2,2 \%)$. Hasil tersebut sedikit menurun jika dibandingkan dengan hasil survei tahun 2009-2011 prevalensi KB cenderung tetap pada kisaran angka 67,5\% (Badan Kependudukan dan Keluarga Berencana Nasional, 2013). Secara nasional hingga bulan Juli 2014 sebanyak 4.309.830 peserta KB baru didominasi oleh peserta Non MKJP yaitu sebesar $69,99 \%$, sedangkan untuk peserta MKJP hanya sebesar 30,01\% (Prawirohardjo, 2014).

Sejalan dengan hasil Data Riset Kesehatan Dasar menunjukkan bahwa pada tahun 2013 wanita usia 15-49 tahun dengan status kawin sebesar $59,3 \%$ PUS menggunakan KB modern
(Implan, MOW, MOP, IUD, Kondom, Suntik dan pil), dan 0,4\% menggunakan KB tradisional (MAL, Kalender dan Senggama terputus). Selain itu sebanyak 24,7\% PUS pernah melakukan KB dan 15,5 tidak melakukan KB. Metode kontrasepsi yang paling banyak digunakan oleh peserta $\mathrm{KB}$ baru ialah suntik sebanyak 48,56\% (Kementerian Kesehatan Republik Indonesia, 2014).

Menurut data BKKBN Provinsi Lampung tahun 2016 diketahui bahwa jumlah peserta KB baru jenis IUD mencapai 8.950.89 PUS (Pasangan Usia Subur) yang merupakan peserta KB baru. Dan padatahun 2015 mengalami peningkatan mencapai 10.235.542 PUS. Wilayah kota Bandar Lampung pengguna alat kontrasepsi IUD mencapai 62.716 akseptor. Sedangkan untuk wilayah KerjaPuskesmas Teluk Betung Selatan mencapai 811.1 akseptor, Puskesmas Teluk Betung Utara mencapai 919 akseptor, Puskesmas Tanjung Karang Timur Bandar Lampung mencapai 8434 akseptor, Puskesmas Tanjung Karang Barat Bandar Lampung mencapai 13443 akseptor, Puskesmas Tanjung Karang Pusat Bandar Lampung mencapai 14928 akseptor, Puskesmas Teluk Betung Barat Bandar Lampun mencapai 333 akseptor, Puskesmas Kedaton Bandar Lampung mencapai 2100 akseptor, Puskesmas Sukarame Bandar Lampung mencapai 1430 akseptor, Puskesmas Panjang Bandar Lampung mencapai 322 akseptor, Puskesmas Sukabumi Bandar Lampung mencapai 1869 akseptor, puskesmas Tanjung Senengg Bandar Lampung mencapai 1033 akseptor, Puskesmas Rajabasa Bandar Lampung mencapai 771 akseptor, Puskesmas Kemiling Bandar Lampung pengguna alat kontrasepsi IUD mencapai 911 akseptor (Nuradila, 2017).

Salah satu dari pelaksanaan program KB adalah untuk membantu keluarga yang sehat dan sejahtera dengan membatasi kelahiran menjadi dua anak saja dalam sebuah keluarga seperti alat kontrasepsi IUD (Intra Uterine Device), implan (susuk) dan sterilisasi. Kontrasepsi IUD merupakan salah satu jenis alat kontrasepsi yang tidak mengandung hormon sehingga sangat efektif digunakan bagi ibu menyusui karena tidak akan mengurangi jumlah serta kualitas air susu ibu, IUD juga akan memulihkan kesuburan setelah alat kontrasepsi dicabut (Sukamti, 2013).

IUD adalah metode kontrasepsi yang paling efektif untuk menjarangkan kehamilan karena tingkat kegagalan kontrasepsi IUD ini sangat kecil 
Hubungan pemakaian alat kontrasepsi IUD dengan tingkat kenyamanan dalam melakukan hubungan seksual

yaitu kurang dari $1 \%$ sehingga pengaruh cukup besar bagi kesehatan reproduksi wanita dan IUD memiliki masa kerja yang panjang, berbeda dengan kontrasepsi hormonal yang dapat berpengaruh pada tubuh dan dapat menimbulkan efek samping secara sistemik. Meskipun IUD merupakan alat kontrasepsi yang sangat baik untuk kesehatan reproduksi ibu serta dapat mengendalikan laju pertumbuhan penduduk namun pengguna IUD ini menurun dibandingkan dengan alat kontrasepsi hormonal yang tinggi menimbulkan resiko bila penggunaannya dalam jangka waktu yang panjang. Selain beresiko biaya kontrasepsi hormonal lebih mahal dibandingkan kontrasepsi non hormonal (Zannah, 2012).

Terdapat beberapa kelebihan menggunakan kontrasepsi IUD, diantaranya penggunaannya yang lebih efisien, karna dalam jangka waktu lama, berbeda dengan kontrasepsi seperti pil dan suntik, yang perlu mengingat jadwal kunjungan ulang, sedangkan kekurangnya ialah, perdaharan pervagina dalam jangka waktu lama, dan perdarahan saat bersenggama (Susanti, 2018).

Keuntungan pemakaian alat kontrasepsi IUD adalah murah dan ekonomis, tingkat kembali kesuburan nya tinggi. Sedangkan kerugian atau efek samping pemakaianalat kontrasepsi IUD yaitu kram yang dialami ketika pemasangan dan ketidaknyamanan ketika haid yang disertai rasa sakit, ekspulsi, infeksi disaluran telur atau organ lain dipinggul yang disertai rasa nyeri dibagian bawah perut dan peningkatan pengeluaran zat dari vagina seperti keputihan hal ini disebabkan produksi cairan yang berlebih (Ratnawati, 2019).

Hubungan seksual yang nyaman dan memuaskan adalah salah satu komponen penting dalam hubungan perkawinan (Wardhani, 2012). Hubungan seksual dikatakan menyenangkan serta memuaskan jika salah satu pihak dapat mencapai kinerja puncak dalam memberikan kenikmatan erotis terbaik dari pasangannya dan juga mendapatkan kenikmatan erotis dari pasangannya (Winarso, 2019). Efek samping pemakaian IUD berkaitan dengan kenyamanan seksual disebabkan jika dalam menggunting benang spiral kurang cukup pendek. Jika benang spiral terlalu panjang menjutai suami merasakan ada rasa tersangkut setiap kali bersenggama, sehingga sering mendorong istri melepas sepiral dan meminta menggantinya dengan kontrasepsi lain (Rokhmah \& Sarwinanti, 2014).
Persentase tingkat kenyamanan pengguna IUD padatahun 2015 mencapai 4.576.234 jiwa data tersebut menunjukan peningkatan yang signifikan dari tahun 2016 yang hanya berjumlah 3.432 .125 jiwa, peningkatan ini disebabkan oleh beberapa faktor, seperti efisiensi pemakaian, kenyamanaan saat berhubungan intim, dan aman untuk menyusui, karena kontrasepsi IUD tidak mempengaruhi volume ASI (Siregar, 2017).

Hasil penelitian ini sesuai dengan penelitian sebelumnya di Sragen yang menunjukkan Pemakai Alat Kontrasepsi IUD dengan tingkat kenyamanan dalam berhubungan seksual $60 \%$ mengatakan tidak ada keluhan saat melakukan hubngan seksual dan secara statistik menunjukkan ada hubungan $(p=$ 0,005) (Wahyuni, 2013).

Berdasarkan studi pendahuluan yang dilakukan peneliti di wilayah kerja Puskesmas Rawat Inap Kemiling Bandar Lampung pada tahun 2017 dengan metode observasi rekammedik bahwa selama tahun 2016 terdapat 160 orang akseptor memakai alat kontrasepsi IUD. Selanjutnya dilakukan wawancara bebas yang dilakukan terhadap 15 orang akseptor yang memakai alat kontrasepsi IUD menyatakan bahwa 11 orang (73.3\%) mengatakan setelah memakai alat kontrasepsi IUD ada rasa ketidaknyamanan saat melakukan hubungan seksual, sepertisensasi rasa menyangkut saat bersenggama, akibat darib enang spiral yang terlalu panjang dan menjuntai. Dan 4 orang $(26.7 \%)$ mengatakan tidak ada masalah saat melakukan hubungan seksual setelah memakai alat kontrasepsi IUD. Berdasarkan latar belakang diatas peneliti tertarik untuk meneliti tentang Hubungan Pemakaian Alat Kontrasepsi IUD Dengan Tingkat Kenyamanan Dalam Melakukan Hubungan Seksual.

\section{METODE PENELITIAN}

Jenis penelitian kuantitatif dengan rancangan Survei Analitik dengan pendekatan cross sectional Populasinya seluruh ibu yang pernah melakukan pemasangan KB IUD yang berjumlah 91 akseptor pada tahun 2017. Sampelnya sejumlah 91 responden menggunakan random sampling. Alat pengumpul data pada penelitian ini adalah dengan menggunakan lembar kuesioner. Penilaian yang dilakukan untuk menilai tingkat kenyamanan berhubungan seksual dengan rentan nilai 1-20. Jika skor nilai 1-11 maka ada masalah dalam kenyamanan berhubungan seksual pada pengguna alat kontrasepsi IUD, dan jika nilai 12-20 maka tidak ada masalah kenyamanan berhubungan seksual pada penggunaan alat kontrasepsi IUD (Sulistyawati, 2011). Telah dilakukan uji validitas $(r$ tabel $=0,549)$ dan reabilitas $(0,778)$. 
Hubungan pemakaian alat kontrasepsi IUD dengan tingkat kenyamanan dalam melakukan hubungan seksual

HASIL

Tabel 1. Karakteristik Responden $\mathrm{N}=91$

\begin{tabular}{lcc}
\hline Variabel & Frekuensi (f) & Persentase (\%) \\
\hline Usia & & \\
$\leq 20$ tahun & 21 & $23,1 \%$ \\
$20-30$ tahun & 34 & $37,4 \%$ \\
$>30$ tahun & 36 & $39,5 \%$ \\
& & \\
Pendidikan & 32 & $35,2 \%$ \\
SD- SMP & 39 & $42,9 \%$ \\
SMA & 20 & $21,9 \%$ \\
Perguruan tinggi & & \\
Pekerjaan & 14 & $15,4 \%$ \\
Wiraswasta & 16 & $17,6 \%$ \\
PNS & 61 & $67,0 \%$ \\
Ibu rumah tangga & & \\
Akseptor & 20 & $22,0 \%$ \\
Memakai alat kontrasepsi selain IUD & 71 & $78,0 \%$ \\
Memakai alat kontrasepsi IUD & & \\
Tingkat Kenyamanan Melakukan & & \\
Hubungan Seksual & & \\
Ada Masalah Kenyamanan & 72 & $20,9 \%$ \\
Tidak Ada Masalah Kenyamanan & 19 & \\
\hline
\end{tabular}

Berdasarkan tabel dapat terlihat bahwa distribusi frekuensi responden pengguna alat kontrasepsi didominasi kategori umur > 30 tahun sejumlah $36(39,5 \%)$ responden, berpendidikan SMA sejumlah 39 responden $(42,9 \%)$ dan kategori sebagai Ibu Rumah Tangga sejumlah 61 responden $(67,0 \%)$. Respoden yang menggunakan alat kontrasepsi IUD sebesar 71 responden $(78,0 \%)$, sedangkan sisanya yang menggunakan alat kontrasepsi jenis suntik, pil, dan implan. Responden yang merasa ada masalah kenyamanan melakukan hubungan seksual sejumlah 72 responden $(79,1 \%)$ dan sisanya merasa tidak ada masalah kenyamanan dalam melakukan hubungan seksual.

Tabel 2. Pemakaian Alat Kontrasepsi IUD dan Tingkat Kenyamanan Melakukan Hubungan Seksual

\begin{tabular}{|c|c|c|c|c|c|c|c|c|}
\hline \multirow{3}{*}{ Akseptor } & \multicolumn{4}{|c|}{ Tingkat kenyamanan } & \multirow{2}{*}{\multicolumn{2}{|c|}{ Jumlah }} & \multirow{3}{*}{$p$-value } & \multirow{3}{*}{$\begin{array}{c}\text { OR } \\
(\mathrm{Cl}=95 \%)\end{array}$} \\
\hline & \multicolumn{2}{|c|}{$\begin{array}{l}\text { Tidak ada } \\
\text { masalah }\end{array}$} & \multicolumn{2}{|c|}{ Ada masalah } & & & & \\
\hline & $\mathrm{n}$ & $\%$ & $\mathrm{n}$ & $\%$ & $\mathbf{N}$ & $\%$ & & \\
\hline $\begin{array}{l}\text { Menggunakan } \\
\text { IUD }\end{array}$ & 19 & 20,9 & 52 & 57,1 & 71 & 78,0 & 0,006 & $\begin{array}{c}4.105 \\
(1.455-11.58)\end{array}$ \\
\hline $\begin{array}{l}\text { Memakai alat } \\
\text { kontrasepsi } \\
\text { selain IUD }\end{array}$ & 12 & 13,2 & 8 & 8,8 & 20 & 22,0 & & \\
\hline Jumlah & 31 & 34,1 & 60 & 65,9 & 91 & 100 & & \\
\hline
\end{tabular}


Hasil dari penelitian maka diketahui bahwa ada perbedaan tingkat kenyamanan melakukan hubungan seksual dari $71(78,0 \%)$ responden yang menggunakan alat kontrasepsi IUD sebesar 52 $(57,1 \%)$ responden yang mengatakan adanya masalah dengan tingkat kenyamanan melakukan hubungan seksual, $19(28,8 \%)$ responden yang menggunakan alat kontrasepsi IUD menunjukan tidak ada masalah tingkat kenyamanan dalam melakukan hubungaan seksual. Sedangkan 20 $(22,0 \%)$ responden yang tidak menggunakan alat kontrasepsi IUD ada sebesar $8(8,8 \%)$ responden mengatakan adanya masalah kenyamanan dalam melakukan hubungan seksual di dan $12(13,2 \%)$ responden menunjukan tidak ada masalah kenyamanan melakukan hubungan seksual. Hasil uji statistik chi square di dapat nilai $p$ value $<a$ $(0,006<0,05)$ yang artinya Ho diterima, dapat disimpulkan ada hubungan yang bermakna pemakaian alat kontrasepsi IUD dengan tingkat kenyamanan melakukan hubungan seksual. OR di dapat 4.105 yang artinya responden yang memakai alat kontrasepsi IUD memiliki resiko lebih besar 4.105 kali ada masalah tingkat kenyamanan melakukan hubungan seksual di bandingkan dengan responden yang tidak menggunakan alat kontrasepsi IUD dan kontrasepsi jenis suntik, pil, implan.

\section{PEMBAHASAN}

\section{Pengguna Alat Kontrasepsi IUD}

Berdasarkan hasil penelitian diperoleh data bahwa distribusi frekuensi responden dengan kategori menggunakan alat kontrasepsi IUD sebesar 71 responden $(78,02 \%)$ responden, sedangkan yang tidak menggunakan alat kontrasepsi IUD sebesar 20 responden $(21,98 \%)$.

IUD (Intra Uterine Device) adalah alat kontrasepsi yang disisipkan ke dalam rahim, terbuat dari bahan semacam plastik, ada pula yang dililit tembaga, dan bentuknya bermacam-macam. Bentuk yang umum dan mungkin banyak dikenal oleh masyarakat adalah bentuk spiral. Spiral tersebut dimasukkan ke dalam rahim oleh tenaga kesehatan (dokter / bidan terlatih). Sebelum spiral dipasang, kesehatan ibu harus diperiksa dahulu untuk memastikan kecocokannya. Sebaiknya IUD ini dipasang pada saat haid atau segera 40 hari setelah melahirkan (Hartanto, 2015).

Hasil penelitian ini sejalan dengan hasil penelitian yang dilakukan oleh Nur Arifah yang hasil penelitian nya menunjukkan bahwa sebanyak 29 responden $(59,2 \%)$ pengguna alat kontrasepsi IUD menyatakan nyaman dalam melakukan hubungan seksual dengan suami dan sebanyak 28 responden $(57,1 \%)$ pengguna alat kontrasepsi non-IUD menyatakan nyaman. Hasil uji chi square dengan nilai $p=0,838$ (nilai $p>0,05$ ).

Dari hasil penelitian diatas peneliti dapat menyimpulkan bahwa responden yang memakai alat kontrasepsi IUD dikarenakan responden telah mendapatkan informasi dari tenaga kesehatan maupun media-media, baik cetak maupun dari media televisi tentang baik dan kualitas alat kontrasepsi IUD yang tidak perlu mengingat-ingat kapan dan tanggal berapa masa haid, serta tidak takut akan ada nya kehamilan yang tidak di inginkan pada masa saat masih dalam keadaan menggunakan alat kontrasepsi IUD. Akan tetapi dapat mengubah tingkat kenyamanan melakukan hubungan seksual, haid akan lebih terasa sakit kram perut, volume darah lebih banyak dan lama, serta rasa tergesernya benang IUD jika saat haid datang.

Sisi negatif dari alat kontrasepsi IUD salah satunya mahal nya biaya pemasangan, alat kontrasepsi ini juga tidak dilengkapi dengan alat pelindung yang bisa mencegah terkena penyakit menular seks, perubahan mood serta nyeri payudara saat sebelum haid.

Pemakaian alat kontrasepsi non IUD juga diplih oleh pasangan suami istri tentu dengan berbagai alasan dari malu menggunakan IUD hingga memikirkan efek samping yang ditimbulkan oleh pengguna alat kontrasepsi IUD. Ada berbagai cara kontrasepsi yang dapat digunakan pada non IUD ini tentu saja masing-masing memiliki kelebihan dan kekurangannya. Hanya saja kontrasepsi non IUD lebih praktis dan sederhana meskipun tingkat keefektifannya lebih akurat dengan IUD. Misalnya saja dengan alat kontrasepsi jenis pil merupakan jenis kontrasepsi oral yang harus diminum setiap hari yang bekerja mengentalkan lendir serviks sehingga sulit dilalui oleh sperma.

\section{Tingkat Kenyamanan Berhubungan Seksual}

Berdasarkan hasil penelitian diperoleh hasil distribusi frekuensi responden yang tidak ada keluhan kenyamanan dalam melakukan hubungan seksual dengan penggunaan alat kontrasepsi IUD sejumlah 19 responden (20,9\%), sedangka yang ada keluhan kenyamanan melakukan hubungan seksual pengguna alat kontrasepsi IUD sejumlah 52 respoden $(57,1 \%)$.

Ketidak nyamanan merupakan suatu perasaan yang kurang ataupun yang tidak menyenangkan bagi kondisi fisik maupun mental pada pasangan suami istri dalam berhubungan seksual. Menurut 
Hubungan pemakaian alat kontrasepsi IUD dengan tingkat kenyamanan dalam melakukan hubungan seksual

(Kasim \& Muchtar, 2019) penggunaan alat kontrasepsi IUD dapat berpengaruh pada kenyamanan seksual karena menyebabkan pendarahan post seksual, ini disebabkan karena posisi benang IUD yang menggesek mulut rahim atau dinding vagina sehingga menimbulkan pendarahan dan bisa menyebabkan keputihan, akan tetapi pendarahan yang muncul ini jumlahnya hanya sedikit, pada beberapa kasus efek samping ini menjadi pembenar bagi aseptor untuk melakukan drop out, terutama dorongan yang salah dari suami (Marlina \& Hidayatulloh, 2018). Hasil penelitian ini sejalan dengan hasil penelitian Sri Wahyuni (2013). Hasil penelitian dari 30 responden menunjukan sebanyak $17 \quad(60 \%)$ responden mengatakan tidak ada keluhan saat melakukan hubungan seksual dan $30 \quad(40 \%)$ responden mengatakan ada keluhan saat melakukan hubungan seksual. Dengan demikian penulis dapat menyimpulkan bahwasannya ibu yang merasa tidak nyaman melakukan hubungan seksual dengan suami di karenakan posisi benang IUD yang menggesek mulut rahim atau dinding vagina sehingga menimbulkan pendarahan dan bisa menyebabkan keputihan. Sedangkan pencetus lain yaitu dalam pemotongan benang IUD terlalu panjang sehingga terasa menjuntai keluar dan suami merasakan seperti kesrimpet benang setiap kali bersenggama, perubahan siklus haid, nyeri payudara, haid akan terasa lebih lama dan banyak, serta saat haid terasa lebih sakit.

Hasil uji statistik chi square didapatkan nilai $p$ value $(0,006<0,05)$ artinya Ho diterima dapat disimpulkan ada hubungan yang bermakna pemakaian alat kontrasepsi IUD dengan tingkat kenyamanan melakukan hubungan seksual. OR didapat dapat 4.105 yang artinya responden yang memakai alat kontrasepsi IUD memiliki resiko lebih besar 5.105 kali ada masalah tingkat kenyamanan melakukan hubungan seksual di bandingkan dengan responden yang tidak menggunakan alat kontrasepsi IUD.

IUD (Intra Uterine Device) adalah alat kontrasepsi yang disisipkan ke dalam rahim, terbuat dari bahan semacam plastik, ada pula yang dililit tembaga, dan bentuknya bermacam-macam. Bentuk yang umum dan mungkin banyak dikenal oleh masyarakat adalah bentuk spiral. Spiral tersebut dimasukkan ke dalam rahim oleh tenaga kesehatan (dokter / bidan terlatih). Sebelum spiral dipasang, kesehatan ibu harus diperiksa dahulu untuk memastikan kecocokannya. Sebaiknya IUD ini dipasang pada saat haid atau segera 40 hari setelah melahirkan (Hartanto, 2015). Ketidak nyamanan merupakan suatu perasaan yang kurang ataupun yang tidak menyenangkan bagi kondisi fisik maupun mental pada pasangan suami istri dalam berhubungan seksual. Menurut (Fauziah \& Siswati, 2017) penggunaan alat kontrasepsi IUD dapat berpengaruh pada kenyamanan seksual karena menyebabkan pendarahan post seksual ini disebabkan karena posisi benang IUD yang menggesek mulut rahim atau dinding vagina sehingga menimbulkan pendarahan dan bisa menyebabkan keputihan, akan tetapi pendarahan yang muncul ini jumlahnya hanya sedikit, pada beberapa kasus efek samping ini menjadi pembenar bagi aseptor untuk melakukan drop out, terutama dorongan yang salah dari suami.

Hasil penelitian ini sejalan dengan hasil penelitian Sri Wahyuni (2013). Hasil penelitian dari 30 responden menunjukan sebanyak 17 (60\%) responden mengatakan tidak ada keluhan saat melakukan hubungan seksual dan $30 \quad(40 \%)$ responden mengatakan ada keluhan saat melakukan hubungan seksual. Dari hasil penelitian diatas peneliti dapat menyimpulkan bahwa responden yang memakai alat kontrasepsi IUD dikarenakan responden telah mendapatkan informasi dari tenaga kesehatan maupun mediamedia, baik cetak maupn dari media televisi tentang baik dan kualitas alat kontrasepsi IUD yang tidak perlu mengingat-ingat kapan dan tanggal berapa masa haid, serta tidak takut akan ada nya kehamilan di masa saat masih dalam keadaan pemasangan alat kontrasepsi IUD. Akan tetapi dapat mengubah tingkat kenyamanan melakukan hubungan seksual, haid akan lebih terasa sakit, volume darah lebih banyak dan lama, serta rasa tergesernya benang IUD jika saat haid datang. Sedangg kan ibu yang tidak memakai alat kontrasepsi IUD dikarenakan ibu takut dengan tanda dan gejala setelah pemasangan kontrasepsi jika benang IUD menjuntai keluar serta rasa tidak nyaman saat melakukan.

Dengan demikian penulis dapat menyimpulkan bahwasannya ibu dan suami yang merasa tidak nyaman melakukan hubungan seksual di karenakan benang IUD yang terlalu panjang saat pemotongan, atau pendek dalam pemotongan benang IUD, sehingga terasa menjuntai keluar suami akan merasakan seperti kesrimpet atau tertusuk ujung benang IUD saat bersenggama. 
Hubungan pemakaian alat kontrasepsi IUD dengan tingkat kenyamanan dalam melakukan hubungan seksual

Gejala lain yang mungkin timbul yaitu keputihan yang berlebih. Gejala tersebut yang akan mendorong suami untuk mengganti jenis kontrasepsi yang nyaman.

Sedangkan dengan responden yang tetap merasakan ketidak nyamanan melakukan hubungan seksual meskipun tidak menggunakan alat kontrasepsi IUD merupakan responden yang telah melakukan post drop out. Adapun efek samping dari post drop out itu sendiri yaitu akan mengalami peningkatan pendarahan menstruasi atau kram, nyeri vagina paska pelepasan, keputihan berlebih, sakit kepala, perubahan mood dan nyeri payudara serta rawan pendarahan paska bersenggama.

\section{SIMPULAN}

Sebagian besar responden memakai alat kontrasepsi IUD, dan sebagian besar mereka mengalami masalah kenyamanan melakukan hubungan seksual yang berkaitan dengan penggunaan alat kontrasepsi tersebut. Ada hubungan antara pemakaian alat kontrasepsi IUD dengan tingkat kenyamanan melakukan hubungan seksual dengan nilai p-value 0,006 dan OR 4.105.

\section{SARAN}

Dapat dijadikan sebagai informasi pada pelayanan puskesmas setempat dan bahan pertimbangan dalam pemecahan masalah pada program kesehatan bidang alat kontrasepi, khususnya masalah kebutuhan sexual dan keharmonisan pasangan suami-istri pada akseptor IUD serta memberikan keterangan yang benar tentang pemakaian alat kontrasepsi IUD, pengecekan posisi benang secara mandiri, dan kebersihan vagina.

\section{DAFTAR PUSTAKA}

Badan Kependudukan dan Keluarga Berencana Nasional. (2013). Kemenkes. Survei demografi dan kesehatan Indonesia 2012. Diakses dari: http://kesga.kemkes.go.id/images/pedoman/SDKI \%202012-Indonesia.pdf

Fauziah, A. N., \& Siswati, B. I. (2017). Hubungan Lama Penggunaan Intra Uterine Device (lud) Dengan Kenyamanan Seksual Di Puskesmas Simo Kabupaten Boyolali Periode Januari-Juni tahun 2011. Jurnal Kebidanan Indonesia: Journal of Indonesia Midwifery, 3(1).
Hartanto, H. (2015). Keluarga Berencana dan Kontrasepsi, Jakarta. Sinar Harapan.

Kasim, J., \& Muchtar, A. (2019). Penggunaan Kontrasepsi lud Terhadap Seksualitas Pada Pasangan Usia Subur. Media Kesehatan Politeknik Kesehatan Makassar, 14(2), 141145.

Kementerian Kesehatan Republik Indonesia. (2014). Profil Kesehatan Indonesia 2013. Diakses dari https://pusdatin.kemkes.go.id/resources/downlo ad/pusdatin/profil-kesehatan-indonesia/profilkesehatan-indonesia-2013.pdf

Marlina, D., \& Hidayatulloh, N. (2018). Fungsi Seksual Akseptor Pengguna Alat Kontrasepsi Dalam Rahim (Akdr). Prosiding Pin-Litamas 1, 1(1), 522-527.

Nurila, D. (2017). Sistem Informasi Manajemen Surat (Smart) Studi Kasus: Bkkbn Provinsi Lampung.

Prawirohardjo, S. (2014). Buku panduan praktis pelayanan kontrasepsi. Jakarta: Yayasan Bina Pustaka Sarwono Prawirohardjo.

Ratnawati, C. (2019). Faktor-Faktor yang Berhubungan dengan Kurangnya Penggunaan Alat Kontrasepsi IUD di Kecamatan Tinggi Moncong Kabupaten Gowa (Doctoral dissertation, Universitas Islam Negeri Alauddin Makassar).

Rokhmah, N. A., \& Sarwinanti, S. (2014). Perbedaan Tingkat Kenyamanan dalam Melakukan Hubungan Seksual pada Pasangan Pengguna Kontrasepsi IUD dan Non IUD di Desa Bligo Kecamatan Ngluwar (Doctoral dissertation, STIKES'Aisyiyah Yogyakarta).

Siregar, D. S. (2017). Analisa Situasi Pengguna Iud Di Puskesmas Suigai Durian Kab. Kubu Raya Tahun 2017 (Doctoral dissertation). 
Hubungan pemakaian alat kontrasepsi IUD dengan tingkat kenyamanan dalam melakukan hubungan seksual

Sukamti, F. A. P. I. (2013). Hubungan Antara Tingkat Pengetahuan lbu Post Partum Tentang Keluarga Berencana Dengan Keputusan Menjadi Aseptor KB Di Puskesmas Kebakkramat 1karanganyar. Jurnal IImu Keperawatan Indonesia Vol, 1(1).

Sumiasih, S. (2018). trend Angka kematian lbu (AKI) Dan Angka Kematian Bayi (AKB) Di Propinsi Jawa Timur Tahun 2011-2015. Jurnal IImiah Kesehatan Media Husada, 7(1), 47-56.

Susanti, D. (2018). Faktor Yang Berhubungan Dengan Penggunaan Alat Kontrasepsi Implant Pada Wanita Pasangan Usia Subur Di Puskesmas Batunadua Kota Padangsidimpuan Tahun 2018 (Doctoral dissertation, Institut Kesehatan Helvetia).
Wardhani, N. A. K. (2012). Self disclosure dan kepuasan perkawinan pada istri di usia awal perkawinan. Calyptra, 1(1), 1-9.

Winarso, H. (2019). Seksualitas Manusia: Masalah dan Solusi. CV Jejak (Jejak Publisher).

World Health Organization. (2011). Atlas of headache disorders and resources in the world 2011. Geneva: World Health Organisation.

Zannah, I. R. (2012). Gambaran keluhan-keluhan akibat penggunaan alat kontrasepsi IUD pada Akseptor IUD di wilayah kerja Puskesmas Sukajadi Kota Bandung. Students e-Journal, 1(1), 28 